\title{
Współpraca naukowa pracowników Wydziału Prawa Uniwersytetu w Białymstoku ze środowiskiem prawniczym Uniwersytetu w Bari
}

Współpraca naukowa między Wydziałem Prawa Uniwersytetu w Białymstoku i Wydziałem Prawa Uniwersytetu w Bari (Facoltà di Giurisprudenza-Università degli Studi di Bari) we Włoszech została nawiązana w roku akademickim 2004/2005. Architektami tego porozumienia byli kierownik Zakładu Prawa Rzymskiego i Kanonicznego Uniwersytetu w Białymstoku, ks. prof. Florian Lempa i prof. Sebastiano Tafaro, wykładający prawo rzymskie na Uniwersytecie w Bari, dziekan zamiejscowego Wydziału Prawa w Tarencie. Kilkuletni okres kontaktów na polu naukowym między wspomnianymi ośrodkami akademickimi stanowi okazję do podsumowania efektów podjętej współpracy.

Wspólne działania zaowocowały między innymi zorganizowaniem kilku konferencji polsko-włoskich. Pierwsza z nich pt. Rodzina i społeczeństwo wczoraj $i$ dziś (La famiglia e la società di ieri e di oggi) miała miejsce 27 listopada 2004 r. na Wydziale Prawa Uniwersytetu w Białymstoku. Kolejną okazją do prezentacji poglądów naukowych stała się konferencja pt. Swobodny przepływ osób i idei w Unii Europejskiej. Problemy migracyjne Południe-Północny-Wschód (La libera circolazione delle persone e delle idee nell'area dell'Unione Europea. Problematica relativa alla migrazione Sud-Nord-Est), która odbyła się 18 maja 2007 r. w murach białostockiej uczelni. W dniach 17-20 września 2007 r. pracownicy naukowi obydwu uniwersytetów spotkali się we Włoszech. Tematem dyskusji, prowadzonych w dwóch uroczych miejscowościach Martina Franca i Taranto (Tarent), była Tutela giuridica della persona e dellambiente nel modello di democrazia partecipativa. Problematyka następnej konferencji włoskich i polskich naukowców koncentrowała się wokół Prawa $i$ wielokulturowości (Diritto e multiculturalità). Pierwszy z paneli dyskusyjnych odbył się 20 czerwca 2008 r. na Wydziale Ekonomiczno-Informatycznym Filii Uniwersytetu w Białymstoku w Wilnie. Zorganizowanie go było możliwe dzięki życzliwości i pomocy władz dziekańskich wspomnianego Wydziału, prof. Jarosława Volkonovskiego i dr Aliny Grynii. Dzień później uczestnicy konferencji zgromadzili się w Białymstoku, gdzie kontynuowali dyskusję na tamtejszym Wydziale Prawa.

Odnotować także trzeba, że pracownicy Wydziału Prawa Uniwersytetu w Białymstoku przyjęli zaproszenie strony włoskiej do wzięcia udziału w kolejnej konferencji pt. Dignitas - dal Diritto Romano alla Carta di Nizza, którą zaplanowano na maj $2009 \mathrm{r}$.

Wymiernym efektem podjętej współpracy naukowej są publikacje zbiorowe. Pierwsza z nich, zatytułowana Rodzina i społeczeństwo wczoraj $i$ dziś (red. S. Tafaro i F. Lempa, Białystok 2006, ss. 267), zawiera 15 opracowań z zakresu 
prawa rzymskiego, kanonicznego, polskiego, włoskiego i unijnego, stanowiących szerokie spektrum poglądów na temat rodziny. Przedstawiciele nauki włoskiej przybliżyli następujące zagadnienia: S. Tafaro, Famiglia e matrimonio: le radici romanistiche; F. Mastroberti, Il diritto di famiglia in Europa tra antico e nuovo regime; E. Cianciola, Famiglia e soggetti deboli: linee per una ipotesi di diritto comune; S. Vinci, L'integrazione dello straniero in Europa. Dal diritto di albinaggio alla tutela dellunità famigliare; F. Parente, Malformazioni fetali e danni esistenziali da procreazione; A. F. Uricchio, Incidenza della normativa fiscale comunitaria sugli asseti della famiglia; M. Casola, Unioni civili, unioni di fatto ed altre convivenze nella legislazione Europea; P. Cristiano, La famiglia ed i valori fondamentali delluomo: ieri ed oggi. La tutela dei minori. Do wymienionych artykułów dołączono streszczenia w języku polskim.

Z kolei prawnicy polscy poruszyli w swych opracowaniach następującą problematykę: R. Sztychmiler (Uniwersytet Warmińsko-Mazurski w Olsztynie), Prawa małżonków i rodziny w prawie kanonicznym; E. Pływaczewski i G. Szczygieł, Kryminologiczne i prawno-karne aspekty przemocy $w$ rodzinie; M. Zdanowicz i K. Bagan-Kurluta, Jedność rodziny w świetle wyroku Trybunatu Sprawiedliwości Wspólnot Europejskich $w$ sprawie Chen; F. Lempa, Znaczenie pokrewieństwa $w$ prawie rzymskim, kanonicznym i polskim a współczesne formy prokreacji; S. Bożyk, Problematyka małżeństwa i rodziny w ustawach zasadniczych Republiki Włoskiej oraz Rzeczypospolitej Polskiej; P. Fiedorczyk, Z dziejów polskiego prawa rodzinnego w XX wieku; K. Szczygielski, Konkubinat w polskim ustawodawstwie diecezjalnym $w$ latach 1918-2004. Powyższe artykuły opatrzone zostały streszczeniami w języku włoskim.

Drugą publikację, będącą pokłosiem wcześniejszych dyskusji, stanowi pozycja Uomo e ambiente. Il Incontro ionico-polacco. Dissertationes (red. F. Lempa, Taranto 2008, 262 strony). Znalazło się w niej 10 artykułów włoskich uczonych. Były to kolejno: A. F. Uricchio, La tassa per la raccolta dei rifiuti solidi urbani; F. Parente, La protezione giuridica della persona dallesposizione a campi elettromagnetici; L. Tafaro, Brevi riflessioni interno ai doveri inderogabili dei migranti nellordinamento comunitario: la capacità contributiva; E. Cianciola, $\mathrm{La}$ „non automaticità" dei provedimenti giurisdizionali in tema di tutela dei diritti fondamentali dellambiente; G. Selicato, Incentivi fiscali e governo sostenibile del territorio; M. Angiulli, Profili fiscali e problematiche ambientali nella gestione delle Risorse idriche; F. Beer, Immigrazione e ricongiungimento del nucleo familiare: tra antichi usi e odierne tendenze; M. Casola, Interesse rei publicae alla salvezza della dote oraz L'immigrato: una riflessione sulle dinamiche d'integrazione; M. Mazzeo, Minori migranti tra radici romanistiche e normativa comunitaria.

W omawianej publikacji zamieszczone zostały także prace polskich naukowców: E. Kowalewskiej-Borys, Zasada domniemania niewinności jako forma prawnej ochrony osoby stojacej pod zarzutem popetnienia przestęsstwa; U. Drozdowskiej, Ochrona praw pacjenta jako części praw człowieka w polskim 
systemie prawnym; A. Zemke-Góreckiej, Privatizzazione nella protezione della salute; T. Mróz i J. Matys, Zadośćuczynienie pieniężne jako podstawowy środek współczesnej ochrony dóbr osobistych na gruncie prawa prywatnego w Polsce; A. Piekutowskiej, Status pracowników migrujących $i$ ich rodzin $w$ Unii Europejskiej; K. Bagan-Kurluty, Realizacja zasady dobra dziecka w przysposobieniu zagranicznym. Wybrane zagadnienia; S. P. Kursy (Wyższa Szkoła Handlu i Prawa im. R. Łazarskiego w Warszawie), Diseredazione come una forma della protezione contro gli attentati nel diritto giustinianeo; K. Szczygielskiego, Kult pamięci osoby zmartej jako dobro osobiste i jego ochrona $w$ prawie polskim. Po artykułach opublikowanych w języku polskim następują streszczenia w języku włoskim.

Pracownicy naukowi Uniwersytetu w Białymstoku gościli także na Wydziale Prawa Uniwersytetu w Bari z wykładami w ramach programu Erasmus. W dniach 9-12 listopada 2006 r. wykłady dla studentów włoskiej uczelni wygłosili: prof. E. Pływaczewski (kierownik Katedry Prawa Karnego, Zakład Prawa Karnego i Kryminologii) w języku angielskim, Migration and crime: central Europe as an example, natomiast ks. prof. F. Lempa (Katedra Nauk Historyczno-Prawnych, kierownik Zakładu Prawa Rzymskiego i Kanonicznego) w języ$\mathrm{ku}$ włoskim, Il problema della formazione della legge nella società pluralistica. W okresie 16-21 września 2007 r. we Włoszech przebywali kolejni naukowcy białostockiej uczelni, którzy prowadzili w języku angielskim następujące zajęcia: prof. T. Mróz (Katedra Prawa Cywilnego, kierownik Zakładu Prawa Handlowego), Damages for non-pecuniary loss as a primary means of presents protection of the personal interests in Private law in Poland, dr E. Kowalewska-Borys (Katedra Postępowania Karnego), The presumption of innocence as the form of the legal protection of the person before accusation, dr K. Szczygielski (Katedra Nauk Historyczno-Prawnych, Zakład Prawa Rzymskiego i Kanonicznego), Cult of remembrance after the deceased person as a personal interests and its protection in Polish law.

Wspomnieć również należy o wyjazdach studentów białostockiego Wydziału Prawa na Wydział Prawa Uniwersytetu w Bari. W roku akademickim 2005/2006 z możliwości tej skorzystały E. Dawidowicz i W. Galej. W roku akademickim 2008/2009 natomiast do Włoch udały się kolejne studentki: M. Bilkiewicz, M. Mackiewicz i A. Zalewska.

Liczne spotkania naukowe stały się także okazją do nawiązania współpracy z członkami włoskich korporacji prawniczych. W jej efekcie dr K. Szczygielski i mgr P. Kołodko gościli w dniach 12-26 stycznia 2008 r. w kancelarii adwokackiej Vincenzo di Maggio w Taranto, gdzie odbyli praktyki w ramach programu Individual Work Programme for Staff Training Mobility Erasmus. W trakcie pobytu we Włoszech pracownicy Zakładu Prawa Rzymskiego i Kanonicznego uzupełniali także literaturę do przygotowywanych prac naukowych. Miejscem kwerendy była znana ze swych bogatych zbiorów Biblioteca del Dipartimento 
di Diritto Romano, Storia e Teoria del Diritto w Bari. Pogłębieniu badań nad włoskim systemem prawnym służył kolejny staż w ramach wspomnianego programu, na który do kancelarii adwokackiej Roberty Rubino w Bari udali się w dniach 27 sierpnia - 2 września 2008 r. dr K. Szczygielski i dr A. Zemke-Górecka. Warto podkreślić również, że w trakcie wizyty w Polsce w 2008 r. prawnicy włoscy gościli w kancelarii adwokackiej A. Zemke-Góreckiej w Białymstoku. Dzięki osobistemu zaangażowaniu Pani mecenas mieli okazję przyjrzeć się działaniu polskiego wymiaru sprawiedliwości. Zagadnieniem, które wzbudziło ich szczególne zainteresowanie był proces informatyzacji naszych sądów.

Podsumowując 5-letni okres współpracy naukowej pracowników Wydziału Prawa Uniwersytetu w Białymstoku ze środowiskiem prawniczym Uniwersytetu w Bari stwierdzić należy, że dotychczasowa wymiana myśli pozwoliła na lepsze poznanie specyfiki obydwu krajowych systemów prawnych i zasad funkcjonowania instytucji państwowych, pogłębienie studiów nad ochroną praw człowieka oraz umożliwiła stworzenie nowych obszarów badawczych, np. w dziedzinie prawnych aspektów migracji ludności w Unii Europejskiej.

Krzysztof Szczygielski 